\title{
The lexical semantics of blaguer: French ways of bringing people together through persuasion, deception and laughter
}

\author{
Sophia Waters \\ University of New England, Australia \\ swaters4@une.edu.au
}

\begin{abstract}
This study presents a lexical semantic analysis of the French verb blaguer and related expressions. This verb belongs to a suite of "French humour practices", and French-English dictionaries translate it as 'to joke'. However, Anglo-specific terminology such as "joke" does not match the conceptual semantics of blaguer and its related noun blague. Relying on Anglospecific terms to categorise culture-specific practices perpetuates conceptual and terminological Anglocentrism. This study furthers the call to avoid the dangers of sustaining Anglocentrism in the theoretical vocabulary of humour studies (Goddard \& Mullan 2020; Goddard 2018; Wierzbicka 2014a).

Working from the assumption that semantic categories reflect particular ways of speaking, thinking, and behaving, this study's goal is to capture the insider perspective that French speakers have about the meaning of the verb blaguer and the noun blague. Making local understandings more obvious and accessible to cultural and linguistic outsiders will increase cross-cultural understanding and foster appreciation for the different ways that speakers construct and interpret their world with words (Levisen \& Waters 2017).

The analytical tool for this study is the technique of semantic explication couched in the simple cross-translatable and culture-neutral words of the Natural Semantic Metalanguage (Goddard \& Wierzbicka 2014). Carefully chosen example sentences are drawn from Google searches (google.fr) of authentic language use of the verb blaguer and the noun blague. Comparative reference is made to the verb 'to joke' from Australian English to highlight the differences in the conversational humour cultures of French and English speakers (Goddard \& Mullan 2020; Béal \& Mullan 2013, 2017).
\end{abstract}

Keywords: lexical semantics, conversational humour, blaguer, register, French, Australian English. 


\section{Introduction}

This paper has two aims: to provide a new interpretation of the conceptual semantics of French blaguer, and the related noun blague, and to contribute to the destabilisation of Anglocentrism in the theoretical vocabulary of humour studies (Goddard \& Mullan 2020; Goddard 2018; Levisen 2018; Wierzbicka 2014a). This paper demonstrates that using culture-neutral terms allows conversational humour researchers to capture the insider perspective of native speakers. This paper begins with a discussion of some of the hazards of using English as the tool of analysis in humour studies. By furthering the call to progress away from using English as the language of analysis, this study shows that "laughing with other people" is a more neutral way of categorising these practices. Investigating in fine detail particular words used by speech communities is important because words catalogue speech practices and capture local social realities (Levisen \& Waters 2017: 2). People live by the words that they use, and these words guide people in everyday meaning-making.

First, I will discuss some of the problems associated with using English as the default analytical tool and argue that "laughing with other people" is a more inclusive alternative to "humour words". This will tie in with some of the recent work and latest developments on French verbs for laughing with other people. Some of the dictionary meanings of the verb blaguer and the noun blague will be presented, and I will propose explications for blague and blaguer using the Natural Semantic Metalanguage.

\section{A problem of categorisation: "humour concepts" or "ways of laughing with other people"?}

Humour has been described as "one of the defining characteristics of humanity" (Howe 2002: 252). While finding things to laugh at and laugh about may be a distinctly human pursuit, the word "humour" is problematic in cross-linguistic research because it does not translate exactly in many languages. It seems to be a universal phenomenon that people laugh when they are with other people, but "humour" is not a universal human concept - even within languages that operate with humour words, there are major differences. The manifestation of "humour" or, more simply, what makes people laugh, how and why something makes others laugh, and the words that people use to talk about this, that is, the discourse that surrounds this practice is certainly not universal. People's understanding of the term humour will be guided by the language that they speak (Goddard \& Mullan 2020: 1). For example, the Danes can talk about humor 'humour' by using synesthetic adjectives. The Danish word humor can be modified by words for physical qualities of form, shapes, colours, tastes, temperatures, and bodily states; for example, the following synesthetic adjectives can modify humor 'humour':

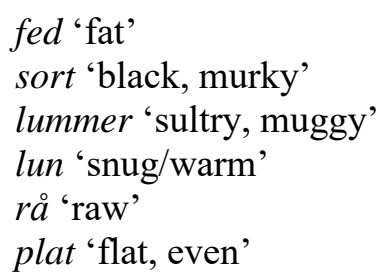

(Levisen 2018: 517)

These synesthetic adjectives all represent emic categories of humour that are specific to Danish (Levisen 2018: 517, cf. 2019). Conducting an ethnopragmatic study of people's discourses on and around humour reveals the ways that the people concerned categorise humorous speech practices in locally meaningful ways. Ethnopragmatics is an ethnographically informed kind 
of pragmatics that studies culturally-specific speech practices. The approach is grounded in a trifold partnership between objective lines of enquiry (posing questions such as what is unique about these speech practices?, and what do speakers themselves understand through this speech practice?), use of a common methodology (the Natural Semantic Metalanguage), and linguistic evidence (Goddard 2006; Goddard \& Ye 2015). The ethnopragmatic approach is a cultural and cognitive approach, which has implications for the non-essentialist framing of research. Levisen and Waters (2015: 255), speaking about Danish ethnopragmatics, explain:

When we talk about 'Danish' ethnopragmatics, we are not taking 'Danish' to refer to a constant, homogeneous, or natural category. The shared sociality of any group of people (whether defined nationally, regionally, religiously professionally, or subculturally) is conceptual, imagined, and constructed. To put it another way, Danish ethnopragmatics is real to the extent that it is 'real to speakers' and reflected in the group's lexicon and related linguistic practices.

The word "humour" has no reliable or neat translation equivalent in French. It was not until 1878 that the French Academy (Académie Française), the overseers of the French language, accepted the word humoristique into the language (Gifford 1981; The Economist, 2003; TLFi). It was then not until much later, in fact 1935, when the Academy formally accepted the noun humour as part of the French language (TLFi). Prior to this, "humour" was seen as a peculiarly English practice. The French, on the other hand, spoke about esprit 'wit', farce 'prank', bouffonnerie 'drollery', and humeur meaning 'state of mind'. In 1761, Voltaire penned a letter to Abbé d'Olivet, the Chancellor of the Académie Française, about this uniquely Anglo practice of "humour", explaining:

[Les Anglais] ont un terme pour signifier cette plaisanterie, ce vrai comique, cette gaieté, cette urbanité, ces saillies qui échappent à un homme sans qu'il s'en doute; et ils rendent cette idée par le mot humeur, humour, qu'ils prononcent yumor; et ils croient qu'ils ont seuls cette humeur; que les autres nations n'ont point de terme pour désigner ce caractère d'esprit. Cependant c'est un ancien mot de notre langue, employé en ce sens dans plusieurs comédies de Corneille.

(Voltaire 1827: 126)

[The English] have a term for this type of joking, this true form of the comic, this gaiety, this urbanity, these remarks which escape from a man without him realising it; and they express this idea by the word humeur, 'humour', which they pronounce yumor; and they believe that they are the only ones to possess this humeur; and that other nations have no word for expressing this type of wit. However it is an old word from our own language, which is used in this sense in several comedies by Corneille.

(Translation from Noonan 2011: 98-99)

Voltaire recognised that although the word humour had its roots in the French language, the English had borrowed it, repurposed it, and made it their own. This passage also recognises that there was some terminological confusion at the time about the English term humour and the French terms humeur and humour (Noonan 2011: 99). The purpose of this example is to highlight that even closely related languages such as English and French can have words that are superficially simple and similar, yet deceptively complex.

In French, two of the words used to refer to categories of humour are the verb blaguer and its related noun blague. By looking at these French words we can uncover a peculiarly French way of viewing the world. This paper continues the ethnopragmatic exploration of how ways of laughing are conceptualised with French verbs and progresses the destabilisation of Anglocentrism in the vocabulary of humour studies (see Goddard \& Mullan 2020; Goddard 2018; Levisen 2018, 2019; Mullan \& Béal 2018; Wierzbicka 2014a). The French verb blaguer belongs to a category of verbs that Goddard and Mullan (2020) call "ways of laughing with 
other people". At first blush it may seem simpler to categorise such terms as "speech acts of humour", "humour-related verbs", or "verbs for joking" as has been the convention in humour studies. However, using terms such as "humour speech act" or "humour-related verbs" makes the definition reliant on English terms. Aside from being words from the English language, these terms are also technical English. Conventional approaches to "conversational humour" have been beset by terminological and conceptual confusion (see Goddard 2018). Technical terminology creates distance between the speakers whose words the scholars are trying to define and the speakers' understanding of their own discourse. Even if a researcher devises an outstanding explanation of a particular term, once that technical term has been released into the wilderness of scholarly discourse, it is not possible to control either its meaning or its use (Goddard 2018: 491). Goddard summarises the terminological cycle, or path from ordinariness to technical (mis)use as follows:

(i) One starts with ordinary English words, poorly defined, then (ii) "technicalizes" them and extends their range, often making some formal adjustments along the way, e.g. using adjective + nominalization combinations or coining back-formations such as a tease, or a bant. (iii) Subsequently there is uptake, i.e. different scholars begin to employ the terms, often using them in slightly different ways from the original authors. (iv) Scholarly debate begins about what the new terms mean or should mean, how the terms relate to one another, etc.

(Goddard 2018: 491)

Relying on the label "humour verb" to categorise the French verb blaguer and the noun blague smuggles in Anglo bias and obscures our view of something that is not from English. The word "laugh" on the other hand, has been shown to exist in almost all languages of the world (Goddard \& Wierzbicka 2016; Wierzbicka 2014b). With this in mind, using this word as part of the category label will not contribute to Anglocentrism in humour studies. Relying on ordinary terms such as "laughing" and "feel good" is a more accurate way of capturing what the speakers themselves understand by the word being defined.

The only "perfect match" between French and English laughter concepts occurs between the words rire and laugh (Goddard \& Mullan 2020: 5). This is a key point because it has been demonstrated that laughter and laughing serve as the linchpin in many humour concepts and practices (Chafe 2007; Goddard 2017; Provine 2000). The word humour relying on the category "humour concepts" or "humour verbs" for languages other than English introduces an Anglo bias and clouds the view of something that is not from English. The more semantically basic term on which to rely is the word "laugh".

To overcome the problems of terminology and Anglocentrism, this paper uses the Natural Semantic Metalanguage (NSM) approach to semantic analysis, which has been successfully applied to humour studies (Goddard 2018; Goddard \& Mullan 2020; Levisen 2018, 2019). The NSM methodology was pioneered by Anna Wierzbicka. Over decades and much crosslinguistic research, she and colleagues have shown that simple universal meanings can be used to make emic categories accessible and comprehensible to linguistic and cultural outsiders. The NSM is a metalanguage of basic concepts known as 'semantic primes' such as 'someone', 'say', 'do', 'think', 'good', 'bad', 'can' and 'because' (see Appendix A for the full list of the Anglo English and French exponents of semantic primes). It is hypothesised that these primes, which are simple units of meaning, are lexicalised across all languages (or nearly all languages) (Goddard \& Wierzbicka 2014; Peeters 2006). These primes can be combined into a short explanatory text, known as an explication. The measure of a good explication is assessed against three criteria: compliance, coherence, and compatibility. The paraphrase must be composed solely of NSM-acceptable lexicon and syntax; it must make sense as a whole, and it must correspond to the range of use for a particular expression and match native speaker intuitions about use (Goddard \& Mullan 2020). Semantic molecules, such as laugh, are 
meanings that function as building blocks in other more complex meanings, and they differ from primes in that they can be explicated into semantic primes (Goddard 2016). The comprehensive list of NSM research publications can be found at https://nsm-approach.net.

This study used a corpus-assisted method of data collection meaning that the data set has been compiled from naturally occurring instances of blague and blaguer. I undertook a series of systematic Google searches to collate my own corpus of example sentences. The initial searches were for blague to familiarise myself with its semantic territory. These searches then became more refined as I searched for phrases such as une blague (a blague) and c'était une blague (it was a blague). This search strategy was fruitful in that it revealed many sites devoted to blagues that can be learnt by rote and recited to others. These sites were rich sources of examples of what constitutes une blague. It became clear that there is a heavy emphasis on language use and saying things for the fun of it or its entertainment value. This correlates with Mullan and Béal's findings on what the French find funny (2018). They found in their data that the French were almost three times as likely to use linguistic play to create humour than the Australians (2018: 461-462). Linguistic play included plays on words, plays on the sounds of words, such as alliteration, putting on an accent, or funny voice, borrowing words from other languages, and the use of exaggeration and understatement (2018: 461). This high preference for linguistic play, language awareness and displays of verbal wit is further corroborated by Lundquist (2014).

For the verb blaguer the same approach was taken - first a wide search for the infinitive form, followed by more specific conjugations, such as je blague (I blague). I also used my own near-native speaker intuition and informal consultations with native speakers. The number of example sentences collected from Google searches is approximately one hundred, a sample of which is used below. The spelling errors and other infelicities in the original have been preserved in the example sentences used in this paper.

\section{French ways of laughing}

Most English and French verbs for laughing with other people do not correspond. Goddard and Mullan (2020) have summarised these as follows:

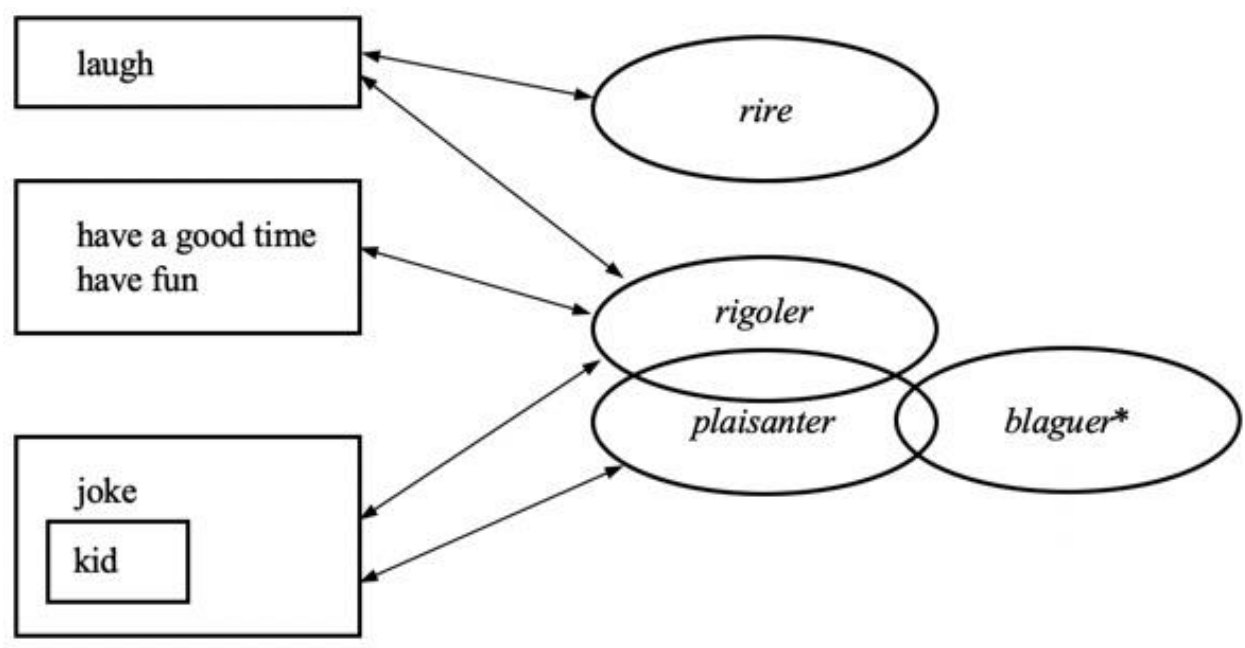

Figure 1. Range of use overlaps and translation correspondence between selected English and French "joking" verbs adapted from Goddard and Mullan (2020: 4). (*my addition to the summary). 
Looking at this figure more closely, French rigoler covers a broad range of English verbs. It can be glossed in English as 'have a good time', 'have fun', 'joke or 'kid', and also as 'laugh' depending on the context. English 'joke' and 'kid' are tightly linked in that 'kidding' seems to be a particular type of 'joking'. The question of language register was raised during my research into these French words for laughing with other people. In one anecdote I was told that in a sophisticated French household On rit, on ne rigole pas 'We laugh (rit), we do not laugh (rigole)'. Initially it looks as though the speaker has made a mistake and said the same thing twice, but the word choice is carefully considered and deliberate. The first word for "laugh" is from the more formal register of French; it sounds "proper". The second word is from the more informal register. An additional perspective to take on this anecdote may be that in that household, a particular type of humour is tolerated and encouraged; a chic and witty humour is expected that incites rires 'laughter', not a coarse or simple one that would make you rigoles. This developed into a discussion about register with regard to plaisanter and blaguer. A comparable match occurs here, too. Blaguer can be classified as part of an informal register, while plaisanter is within the formal register. A plaisanterie has a lightness to it while a blague can be comparatively dull-witted and less refined. This is not to say that linguistic skill and a modicum of wit are not present in blague - they are, as we shall see in the examples. Looking to plaisanter, this verb can also be translated as 'joke' or 'kid', but it has been shown to be primarily about doing or saying something for "pleasure". A French language dictionary reveals that plaisanter's etymological root is in the verb plaire 'to please' and that it is closely related to plaisant 'pleasant or pleasing' (Rey-Debove \& Rey 2005). One verb that I would like to add to this set is blaguer. My research has shown that its best translations in English are 'joke' and 'kid', that its range of use shows some semantic overlap with plaisanter, and that it occupies a semantic space very near to rigoler.

\section{Blaguer, blague: deception and persuasion}

This section will present a semantic profile of blaguer, with some commentary on the related noun blague. Beginning with a brief comparison of French to English, this section covers a novel conceptual analysis of blague and blaguer. A survey of French dictionaries and other semantic commentary shows that blague has two meanings (Rey-Debove \& Rey 2005; cnrt.fr 2019a, 2019b; Maurin, Pacault \& Galès, 2014: e386; TLFi 2019). The first is a small tobacco bag, and the second is an imagined story that people try to make others believe. In dictionaries, the first listed synonym for this meaning is mensonge 'lie'. These two meanings provide a case for two-way polysemy. The noun blague is polysemous because of the shared meaning referring to something that is inflated, puffed up or swollen (Redfern 1996: 395).

English also has the words blague and blaguer, which are direct borrowings from French. The Australian Oxford Dictionary lists the noun blague /bla:g/ as meaning humbug or claptrap (2004b). Someone who talks pretentious nonsense and tells tall stories is a blagueur /bla:' gə/ (Redfern 2005; The Oxford English Dictionary 1989). In addition to these direct lexical borrowings, English also has the nouns blag and blagger $^{1}$, and the verb blag. The origin of these words is said to be late nineteenth century French blaguer 'to tell lies' (OUP 2019a). The connection between these and the French words cannot be ignored. They have simply been semantically adjusted to suit the needs of the English speakers. Looking at these words in more detail in the Oxford English Dictionary, we see that the noun blag /blæg/ is from the informal register and that its first meaning refers to an act of using persuasion or guile to obtain

${ }^{1}$ The noun "blaggard" appears to be a variant spelling of the word blackguard /'blæga:d/ (Australian Oxford Dictionary Online; Mayes 2002; Partridge 1984). It means scoundrel, villain and unscrupulous or unprincipled person. These semantics tie in with the idea of trickery or lying and lack of regard for others. 
something; its second meaning refers to a violent robbery or raid. Moving to the transitive verb blag, similarly to the noun, it means to manage to obtain something by using persuasion or guile. It also means manage to obtain (private or confidential information) by impersonation or other method of deception. Its second listed meaning is to 'steal something in a violent robbery or raid' (OUP 2019b). The online Cambridge Dictionary explains that to blag means 'to persuade someone in a clever or slightly dishonest way to allow you to do something or to give you something' (2019a). The synonyms are cheating and tricking.

Australian English also has the noun blag /blæg/ and the verb blag, but the focus is very much on violence. The noun, listed as colloquial, means a robbery or theft, especially with violence (Australian Oxford Dictionary 2004a). The verb means to rob or steal, and again, this is qualified with 'especially with violence' (Australian Oxford Dictionary 2004a).

To highlight the saliency of blag in everyday English, the following example sentence is a tweet written by Jo Elvin, an Australian-born magazine editor who has been living and working in the UK since the 1990s. This example shows the admiration and good feeling associated with bearing witness to a good blag. ${ }^{2}$

(1) Unusually, enjoying a girl's loud phone chat on train. Seems her mate's blagged a French teaching job with 'Joey from Friends' level French

For a little more context, the "'Joey from Friends' level French" refers to an episode of the hit sitcom in which Joey auditions for a role in a play that requires him to speak French ${ }^{3}$. Despite having had some language lessons, Joey cannot speak French, but he is undeterred. His version of speaking French involves adopting a fake French accent and making a series of disconnected nasal vowel sounds punctuated with grand gesticulations. Applying this to Elvin's tweet, the girl's friend has cleverly managed to secure herself a job through persuasion and saying things that are not true.

Moving back to the French, let us look more closely at blaguer and blague and where they sit in the domain of French verbs for pleasant "laughter talk" with other people. It has already been established that most French and English verbs in the domain of humour do not match.

French humorous discourse has a link to courtly behaviour in that one shows their social standing via a display of intellect. The French value a combination of being funny and cultured. Studies have found that French conversational humour tends towards a preference for wordplay and steers away from making personal comments about others. Wordplay is not nearly as important to the Anglos as it is to the French. Béal and Mullan in their comparative study, found that linguistic play (play on words, alliteration, putting on an accent or funny voice, lexical borrowings) as a humour device is favoured twice as much by the French as it is by the Australians (2018: 461-2). This is very different to Australians who delight in showing and reaffirming their close connection to others by saying bad things about them (Mullan \& Béal 2018; Goddard 2006). Informal consultations with French native speakers have also confirmed this trend, with one declaring that true mastery of French humour is the ability to vulgarise the intellectual or cultured for the entertainment of others.

The focus on linguistic play was obvious in the examples of use of blaguer and blague. Below are some example sentences taken from the style and beauty website DORÉ. The site is headed by Corsican born Garance Doré. She writes her posts in French and has them translated

\footnotetext{
${ }^{2}$ Please note that italics are used in English examples to highlight the word under investigation; plain font will be used in the French examples.

3 2004, 19 February. The One Where Joey Speaks French. [Episode 1013], Carlock, R. \& Knoller, W. (producers), Friends.
} 
into English, and both versions appear on her site ${ }^{4}$. Her writing style creates intimacy with her readers. Her blog posts written using the first-person perspective, and this creates an atmosphere of sharing her thoughts with friends. This intimate relationship is reflected in her language use with many informal expressions and the occasional swear word. The use of asides, often in brackets to offset them from the main text, further strengthen the familiarity and relaxed tone of Garance's writing voice. Her writing often closely resembles speech in that pauses and interjections are used.

(2) Comment cacher l'incachable?

Faire des blagues à la con. Genre: Je suis mannequin détail pour Clearasil. (nul) Nul! Mais les blagues nulles, c'est parfait pour montrer qu'on est cool avec soi-même et bien dans sa peau.

'How do you hide the unhideable? Make stupid jokes (blagues à la con). Like: I don't have to give up on a modelling career. I can still be a hand model. But stupid jokes (blagues nulles) are perfect to show that you're totally cool with yourself and in your own skin.'

The translation above is the one that is provided by the website. I have reproduced the original French phrase in italics and brackets next to the English translation for ease of reference. The English translation loses some of the cleverness of the French original. French speakers would understand that a closer translation of Je suis mannequin détail pour Clearasil is something like 'I'm a model for Clearasil'. Clearasil is an acne treatment product. At the risk of explaining the blague into nothingness, this example actually has two blagues within it. First is the obvious one about the author making light of her pimply skin by proclaiming she is a model for a line of acne treatment products. The second is the play on words between 'Clearasil', a cream for acne prone skin, and feeling good in one's peau 'skin'.

Example (3) is also from Garance Doré. Here she laments the apartments she has rented in New York and Paris.

(3) Mes appartements à New York n'avaient jamais été géniaux, mon apart à Paris avait été tellement nul que c'était une blague - et avant ça, tout me semble être la préhistoire de ma vie.

'My apartments in New York were never great, my apartment in Paris had been so ugly, it was a joke (une blague) - and anything before that seems like a prehistoric part of my life.'

The common theme that is emerging is that the speaker is saying something that cannot be true; they have said something that people can know cannot happen if they think about this something well. This follows through clearly in the next example, also from the DORÉ site. In (4) Garance advises readers, many of whom are Anglophone, on things Parisians do while they are in the famous Left Bank café, Café de Flore.

(4) Aller au Flore, mais pas du côté touristes. Les Parisiens ont leurs zones, voyez-vous. Prétendre qu'ils connaissent les garçons de café et Frédéric Beidbeger. "Ouais, c'est un pote. Ouais, il est passé sans me dire bonjour là, mais c'est une blague entre nous, tellement on est potes, tu vois?"

\footnotetext{
${ }^{4}$ Appendix B lists the webpage and date of access for each example sentence. Example sentences from DORÉ have two entries: one for the French webpage and one for the English version. I have used the translations provided on DORÉ.
} 
'Go to the Flore, but not on the tourist side, ew. Parisians have their zones, you guys. Pretend that you know the waiter and Frederic Beidbeger (notorious Parisian party animal/writer) "Yeaaah, he's a friend. Yeaah, he didn't say hello right NOW, but that's a game (blague) between us, because we're such good friends, you see?"'

Here the game is to convince the other customers through deception that you are Parisian and friends with a celebrity: a true Parisian knows the side to which other Parisians flock in Hemingway's former haunt. With this in mind, it is crucial to behave as though you own the place.

French humour or French ways of laughing with other people often involve displays of wit and cleverness. We will now move away from uses of the word blague to see some examples of blagues in the sense that they can be learnt, committed to memory and then repeated to others. The French version of Siri, Apple's voice controlled personal assistant available on a series of their products, has a set of blagues. I used the phrase Dis Siri, raconte-moi une blague, $s$ 'il vous plaît and was told a series of blagues. Example (5) was delivered by Siri, but it is also available on some websites listing French blagues. This blague is a spin on the classic 'A man walked into a bar...' frame.

(5) C'est un squelette qui entre dans un bar et dit: "Donnez-moi un verre...et une serpillière. "

"A skeleton walks into a bar and says: "Give me a drink...and a mop.",5

This blague, believe it or not, is funnier and smoother in French. It hinges on the alliteration of the $/ \varepsilon /$ phoneme in verre and serpillière. A variation of this blague is to replace verre with bière 'beer', which also has the / $/$ / sound. The English words 'drink' and 'mop' do not have quite the same pleasing ring to them. While the English version falls flat with a groan, the French version shows wit and linguistic deft. Showing oneself to be clever or witty are highly valued in French culture (Lundquist 2014).

This next blague was discovered on a French language learning website and was one of a set of ' 13 Silly French Jokes You Need to Understand to Truly Feel French' (Houy 2018). This blague is what Australians would describe as being like Vegemite ${ }^{6}$ - it will inspire either love or hate. This dark and absurd blague is said to have first appeared on the inside of a Carambar wrapper (Professeur V 2017). Created in France in 1954, these chewy caramel bars are known for the blagues that have been printed on the inside of the wrapper since the late 1960s. The confectionary company invited people to submit their blagues, paying 70 euros for each accepted piece that adhered to the guidelines of avoiding talk of death, politics, sex, or anything serious. The printing of the blagues stopped in 2013. The 'pas de bras, pas de chocolat' blague is a brief exchange between a young boy (A) and his mother (B).

(6) A: Maman, je peux avoir du chocolat?

B: Il y en a dans le placard, va donc te servir.

A: Mais maman, je peux pas, tu sais bien que je n'ai pas de bras...

B: Pas de bras, pas de chocolat!

'A: Mum, can I have some chocolate?

\footnotetext{
${ }^{5}$ Unless otherwise stated, all translations are my own.

${ }^{6}$ Vegemite is a yeast-based savoury spread that is popular in Australia. Its distinctive flavour is divisive.
} 
B: There's some in the cupboard. Go help yourself.

A: But mum, I can't, you know very well that I don't have arms...

B: No arms, no chocolate!'

This blague has been made famous in several television advertisements, as well as in the 2011 film Les Intouchables 'The Intouchables'. In the scene, Driss (Omar Sy) accompanies his boss Philippe (François Cluzet), a quadriplegic, to an art gallery so that Philippe might purchase some artwork. Philippe is looking at a painting while his carer is nonchalantly eating M\&Ms. Philippe says, Donnez-moi un chocolat 'Give me a chocolate' and waits, mouth open, for his carer to oblige. This first request is refused, so Philippe repeats the phrase. Driss, not missing a beat, responds deadpan, Pas de bras, pas de chocolat 'No arms, no chocolate'. Philippe is dumfounded. Driss explodes into laughter, explaining that he was pulling his boss's leg. It was une blague. This blague, although cruel and absurd, shocks and delights listeners through its content and sound through the alliteration of /a/ of which the French are so fond (see Mullan \& Béal 2018).

Below is an excerpt from an interview with one of the writers of the Carambar blagues. He was asked to share his favourite blague:

(7) La blague que Stéphane a préférée? Elle n'a finalement pas été retenue mais il la partage quand même avec les auditeurs : "Quel est le super héros des plombiers? C'est Robinet Batman ».

'What is Stéphane's favourite joke (blague)? It ultimately wasn't accepted, but he shares it with listeners anyway: "Who's a plumber's favourite superhero? Robin and Batman (Robinet Batman).",

For non-Francophones, the validity of this joke will be questionable without some explanation. The word robinet /Robine/ means 'tap' or 'faucet', which are essential fittings in any plumber's kit. The noun robinet sounds very similar to the first name of one half of the superhero duo, Robin, and the conjunction 'and' et.

Continuing with the French penchant for word play in blagues, and similar in type to example (7), example (8) is a blague went viral on YouTube in 2017 (Twinsmatique Jules et Adrien 2017). The clip shows a young boy (A) earnestly telling his blague to an unseen listener (B). He starts and is cut off as the listener interjects with C'est quoi la blague? 'What's the blague?', which is notable because it is evidence of an emic categorisation of this type of way of laughing with other people. The boy repeats himself and completes his blague:

(8) A: Qu'est-ce qui est jaune et qui attend?

B: Je ne sais pas.

A: Jonathan (jaune+attend)

'A: What's yellow and waiting?

B: I don't know.

A: Jonathan.'

The boy's idiosyncratic delivery coupled with the ridiculous nature of the blague is highly appealing, and the clip has had well over 9 and a half million views on YouTube. This blague hinges on the homophony, that is, the phonetic similarity of words jaune and attend and the name Jonathan. This type of word play could be categorised as a pun where the hearer retains the relevant two meanings of the word sounds (Dynel 2009: 1290). However, relying on an English categorisation would perpetuate Anglocentrism, which is not appropriate. 
The elements of meaning above have been represented in explication [A].

[A] blague - il raconte une blague ('he tells a blague')

a. it can be like this:

someone says something with some words in a place where there are other people this someone says these words because he/she thinks like this: "I want people here to laugh [m]"

b. these words are like this:

when someone hears these words, he/she can think about these words for some time

when someone hears these words, he/she can know that some people can feel bad when they hear them

c. this someone can think about these words like this: "this can't be true"

at this moment, this someone doesn't know why he/she said it

a moment after, this someone can know why he/she said it

d. if someone thinks like this, he/she can laugh [m]

he/she can feel something good for a short time, like people often feel when they laugh [m]

Explication [A] opens with component (a) which establishes the intention behind une blague: people want other people to laugh typically because of something that was said. This component also captures the social element involved with blague. The notation [m] sits beside the word "laugh" to indicate its status as a semantic molecule" (Wierzbicka 2014b). The blague itself requires some thought on behalf of the hearer as captured in component (b). This component also carries the idea of blague being from an informal register by stating that if it were delivered to the wrong audience, that audience may feel offended ("bad"). Component (c) represents the idea that a speaker wants the hearer to be slightly perplexed by what was said and then enjoy the realisation that the speaker does not actually mean what they said. The humorous intent of the blague is captured in (d).

Moving on to the verb blaguer, let us look at some example sentences to ascertain the range of use. Examples (9)-(12) attest that blaguer is a social pursuit, and something that people engage in with people that they know well or at least feel comfortable enough around to let their guard down. It embodies the idea of spending time with other people and feeling good towards these other people. The informal register that might be used when chatting with friends comes through clearly, so it is notable that the verb choice is blaguer rather than plaisanter in these examples.

(9) J'engloutis un pain au chocolat et je commence à blaguer avec Julia, super photographe, qui va m'assister sur le shooting.

'I scarf down a chocolate croissant and joke around (je commence à blaguer) with Julia, a great photographer, who is going to help me out with the shoot.'

(10) J'adore jurer...La première fois, ça m'a surpris. Je me demandais d'où m'était venue l'expression.

J'étais en train de blaguer avec une copine et soudain, je l'ai appelée bitch $^{8}$, ce qui l'a fait hurler de rire.

'I love swearing...It took me by surprise the first time. I wondered where it came from.

\footnotetext{
${ }^{7}$ Semantic molecules are decomposable into semantic primes and work as building blocks in the meaning of other more complex words.

${ }^{8}$ Emphasis in the original has been preserved by using plain font.
} 
I was joking around (en train de blaguer) with a friend when suddenly I called her "such a bitch," which had her totally cracking up.'

(11) Avec ma tenue de roadie, je me suis sentie pas si mal, finalement. On a toutes blagué sur nos tenues de combat, et on était bien satisfaites de nous.

'With my roadie outfit on, I was feeling pretty ok fashion-wise, actually. We all joked about (blagué sur) our combat outfits and were very satisfied with ourselves, patting each other on the shoulder.

(12) Il regardait les images qu'il avait faites la veille sur son ordinateur. Il était souriant, entouré et n'arrêtait pas de blaguer.

'He was looking through some pictures he had taken the day before, smiling, surrounded by others, and he kept on joking around (n'arrêtait pas de blaguer).

These aspects of meaning are captured in explication [B].

\section{[B] Tiphaine était en train de blaguer ('Tiphaine was blaguer')}

a. she (i.e. Tiphaine) said something like people often do when it is like this:

she was with some other people for some time

she felt something good towards these other people at this time

b. when she said something like this, she thought like this:

"I know" these people here well

because of this I can say some things

I know these people will not feel something bad when they hear these things

when they hear these things, they can think like this: "this can't be true"

at this moment, these people don't know why I said it

a moment after, these people can know why I said it

c. she said it because she wanted people here to feel something good for some time

like people often do when they laugh [m]

Similar to plaisanter, blaguer involves sociability via being with people for some time and having positive feelings towards them (cf. Goddard \& Mullan 2020). An element of meaning that is present in blaguer but not in plaisanter is the idea of knowing well the people one is with, or at least feeling as though one does. The idea of being able to blaguer with someone demonstrates a level of closeness and friendship which would be akin to being able to use the informal register (tutoyer) someone rather than remain in the formal register (vouvoyer). Blaguer similarly contains the idea of saying something for effect. This may be carried out by momentarily confusing the hearer who can then quickly ascertain that what was said, may not have been what was meant.

\section{Concluding remarks}

Understanding non-universal words for "laughing with others", such as blaguer and blague can help humour researchers understand how communities of speakers catalogue speech practices according to their own local norms. The merits of using the NSM approach are twofold: it

\footnotetext{
${ }^{9}$ Technically-speaking, the expression 'know someone' is not a semantic prime; it is a semantic molecule.
} 
achieves an insider perspective and minimises the risk of terminological Anglocentrism marring the results.

It is important that steps in humour studies continue to be taken to disrupt the pervasive Anglocentrism. This disruption can be progressed by investigating ways of laughing with other people in other languages such as has been achieved with this novel conceptual analysis of blaguer and blague. The French ways of thinking that have been represented in this ethnopragmatic study show that sociability, linguistic skill, and cleverness are a primary focus in blaguer and blague. These words embody a sociable space where people feel comfortable to let others in to the familiar circle.

\section{Acknowledgements}

A previous version of this paper was presented at the Australasian Humour Studies Network at RMIT University, Melbourne, February 2019. Thank you to the participants for their thoughtprovoking questions and discussion. I would also like to thank Kerry Mullan, Carsten Levisen and the two anonymous reviewers for their generous and constructive comments on this study. 


\section{Appendix A}

Table 1. Semantic primes, French and English exponents (Peeters 2015). ${ }^{10}$

\begin{tabular}{|c|c|}
\hline JE, TU, QUELQU'UN, QUELQUE CHOSE CHOSE, GENS, CORPS & \multirow[t]{2}{*}{ substantives } \\
\hline I, YOU, SOMEONE, SOMETHING THING, PEOPLE, BODY & \\
\hline TYPES, PARTIES & \multirow{2}{*}{$\begin{array}{r}\text { relational } \\
\text { substantives }\end{array}$} \\
\hline KINDS, PARTS & \\
\hline CE, LA MÊME CHOSE, AUTRE & \multirow[t]{2}{*}{ determiners } \\
\hline THIS, THE SAME, OTHER ELSE & \\
\hline UN, DEUX, CERTAINS, TOUS, BEAUCOUP, PEU & \multirow[t]{2}{*}{ quantifiers } \\
\hline ONE, TWO, SOME, ALL, MUCH MANY, LITTLE FEW & \\
\hline BIEN, MAL & \multirow[t]{2}{*}{ evaluators } \\
\hline GOOD, BAD & \\
\hline GRAND, PETIT & \multirow[t]{2}{*}{ descriptors } \\
\hline BIG, SMALL & \\
\hline SAVOIR, PENSER, VOULOIR, NE PAS VOULOIR, SENTIR, VOIR, ENTENDRE & \multirow[t]{2}{*}{ mental predicates } \\
\hline KNOW, THINK, WANT, DON'T WANT, FEEL, SEE, HEAR & \\
\hline DIRE, MOTS, VRAI & \multirow[t]{2}{*}{ speech } \\
\hline SAY, WORDS, TRUE & \\
\hline FAIRE, ARRIVER, BOUGER & \multirow{2}{*}{$\begin{array}{l}\text { actions, events, } \\
\text { movement }\end{array}$} \\
\hline DO, HAPPEN, MOVE & \\
\hline ÊTRE (QUELQUE PART), IL Y A, ÊTRE (QUELQU'UN/QUELQUE CHOSE) & \multirow{2}{*}{$\begin{array}{r}\text { location, existence, } \\
\text { specification }\end{array}$} \\
\hline BE (SOMEWHERE), THERE IS, BE (SOMEONE/SOMETHING) & \\
\hline (EST) À MOI & \multirow[t]{2}{*}{ possession } \\
\hline (IS) MINE & \\
\hline VIVRE, MOURIR & \multirow[t]{2}{*}{ life and death } \\
\hline LIVE, DIE & \\
\hline $\begin{array}{l}\text { QUAND MOMENT FOIS, MAINTENANT, AVANT, APRĖS, LONGTEMPS, PEU DE TEMPS, } \\
\text { POUR QUELQUE TEMPS, INSTANT }\end{array}$ & \multirow[t]{2}{*}{ time } \\
\hline $\begin{array}{l}\text { WHEN TIME, NOW, BEFORE, AFTER, A LONG TIME, A SHORT TIME, } \\
\text { FOR SOME TIME, MOMENT }\end{array}$ & \\
\hline OÙ ENDROIT, ICI, AU-DESSUS, AU-DESSOUS, LOIN, PRĖS, CÔTÉ, DANS, TOUCHER & \multirow[t]{2}{*}{ place } \\
\hline WHERE PLACE, HERE, ABOVE, BELOW, FAR, NEAR, SIDE, INSIDE, TOUCH & \\
\hline NE...PAS, PEUT-ÊTRE, POUVOIR, À CAUSE DE, SI & \multirow[t]{2}{*}{ logical concepts } \\
\hline NOT, MAYBE, CAN, BECAUSE, IF & \\
\hline TRÈS, PLUS & \multirow{2}{*}{$\begin{array}{l}\text { intensifier, } \\
\text { augmentor }\end{array}$} \\
\hline VERY, MORE & \\
\hline COMME FAÇON & \multirow[t]{2}{*}{ similarity } \\
\hline LIKE AS WAY & \\
\hline
\end{tabular}

Notes: - Exponents of primes can be polysemous, i.e. they can have other, additional meanings $\bullet$ Exponents of primes may be words, bound morphemes, or phrasemes $\bullet$ They can be formally complex - They can have language-specific combinatorial variants (allolexes, indicated with $\sim$ ) $\bullet$ Each prime has well-specified syntactic (combinatorial) properties.

\footnotetext{
${ }^{10} \mathrm{https}$ ://intranet.secure.griffith.edu.au/schools-departments/natural-semantic-metalanguage/downloads
} 


\section{Appendix B}

The number in ( ) corresponds to the example number in the paper. Two URL entries means that there was a translation provided by the source webpage.

(1) https://twitter.com/jo_elvin/status/1095607066440486912 Accessed 22/2/2019

(2) http://www.atelierdore.com/fr/beauty/comment-cacher-lincachable/ Accessed 21/12/2018 https://www.wearedore.com/beauty/comment-cacher-lincachable/ Accessed 21/12/2018

(3) http://www.atelierdore.com/fr/garance/diary/romantique/ Accessed 18/12/2018 http://www.atelierdore.com/garance/diary/romantique/ Accessed 18/12/2018

(4) http://www.atelierdore.com/fr/illustrations/things-parisians-do/ Accessed 21/12/2018 http://www.atelierdore.com/illustrations/things-parisians-do/ Accessed 21/12/2018

(6) https://frenchtogether.com/french-jokes/ Accessed 31/8/2018

(7) https://www.nouvelobs.com/societe/20130322.OBS2709/carambar-l-auteur-etait-paye-70euros-la-blague.html\%20Accessed\%203/1/2019 Accessed 31/8/2019

(8) http://www.atelierdore.com/fr/style/premiere/ Accessed 21/12/2018 http://www.atelierdore.com/style/premiere/ Accessed 21/12/2018

(9) http://www.atelierdore.com/fr/style/premiere/ Accessed 21/12/2018 http://www.atelierdore.com/style/premiere/ Accessed 21/12/2018

(10) http://www.atelierdore.com/fr/illustrations/bitch-talking-shit/ Accessed 21/12/2018 http://www.atelierdore.com/illustrations/bitch-talking-shit/ Accessed 21/12/2018

(11) http://www.atelierdore.com/fr/photos/lauren-2/ Accessed 21/12/2018 http://www.atelierdore.com/photos/lauren-2/ Accessed 21/12/2018

(12) http://www.atelierdore.com/fr/photos/le-paradis/ Accessed 21/12/2018 http://www.atelierdore.com/photos/le-paradis/ Accessed 21/12/2018

\section{References}

Australian Oxford Dictionary, $2^{\text {nd }}$ edition. (2004a). "blag, n. and blag, v." Retrieved 23 December, 2018 from https://www.oxfordreference.com/

Australian Oxford Dictionary, $2^{\text {nd }}$ edition. (2004b). "blague, n." Retrieved 23 December, 2018 from https://www.oxfordreference.com/

Australian Oxford Dictionary, $2^{\text {nd }}$ edition. (2004c). “blackguard, n.” Retrieved 15 January, 2020 from https://www.oxfordreference.com/

Béal, C. \& Mullan, K. (2013). 'Issues in conversational humour from a cross-cultural perspective: Comparing French and Australian corpora', in Peeters, B., Mullan, K. \& Béal, C. (eds.), Cross-Culturally Speaking, Speaking Cross-Culturally, Newcastle upon Tyne: Cambridge Scholars, pp. 107-140.

Béal, C. \& Mullan, K. (2017). 'The pragmatics of conversational humour in social visits: French and Australian English'. Language \& Communication 55, pp. 24-40. Doi: 10.1016/j/ langcom. 2016.09.004

Cambridge Dictionary Online. (2019a). "blag, v.”. Retrieved 1 July, 2019 from https://dictionary.cambridge.org

Cambridge Dictionary Online. (2019b). “blagger, n.”. Retrieved 1 July, 2019 from https://dictionary.cambridge.org

cnrt.fr (Centre National de Ressources Textuelles et Lexicales) (2019a) “blague, n.”. Retrieved 27 January, 2019 from http://cnrtl.fr/etymologie/blague

cnrt.fr (Centre National de Ressources Textuelles et Lexicales) (2019b) “blaguer, vb.". Retrieved 27 January, 2019 from http://cnrtl.fr/etymologie/blaguer

Chafe, W. (2007). The Importance of Not Being Earnest: The Feeling Behind Laughter and Humor. Amsterdam: John Benjamins. 
Dynel, M. (2009). 'Beyond a joke: Types of conversational humour'. Language and Linguistics Compass 3 (5), pp. 1284-1299.

Gifford, P. (1981). 'Humor and the French mind: Towards a reciprocal definition'. The Modern Language Review 76 (3), pp. 534-548.

Goddard, C. (2006). "'Lift your game, Martina!' - Deadpan jocular irony and the ethnopragmatics of Australian English', in Goddard, C. (ed.), Ethnopragmatics: Understanding Discourse in Cultural Context, Berlin: Mouton de Gruyter, pp. 65-97.

Goddard, C. (2016). 'Semantic molecules and their role in the NSM lexical definitions'. Cahiers de lexicologie 109, pp. 13-36.

Goddard, C. (2017). 'Ethnopragmatic perspectives on conversational humour, with special reference to Australian English'. Language \& Communication 55, pp. 55-68.

Goddard, C. (2018). "“Joking, kidding, teasing": Slippery categories for cross-cultural comparison but key words for understanding Anglo conversational humour'. Intercultural Pragmatics, Special Issue: "Conversational humour: Forms, functions and practices across cultures”, Béal, C. \& Mullan, K. (eds.), 15 (4), pp. 487-514. Doi: 10.1515/ip-2018-0017

Goddard, C. \& Mullan, K. (2020). 'Explicating verbs for "laughing with other people" in French and English (and why it matters for humor studies)'. Humor: International Journal of Humor Research 33 (1), 55-77. Doi: 10.1515/humor-2017-0114

Goddard, C. \& Wierzbicka, A. (2014). Words and Meanings: Lexical Semantics across Domains, Languages and Cultures. Oxford: Oxford University Press.

Goddard, C. \& Wierzbicka. (2016). 'Explicating the English lexicon of "doing and happening"'. Functions of Language 23 (2), 214-256. Doi: 10.1075/fol.23.2.03god

Goddard, C. \& Ye, Z. (2015). 'Ethnopragmatics', in Sharifian, F., (ed.), The Routledge Handbook of Language and Culture, London: Routledge, pp. 66-83.

Houy, B. (2018). 13 silly French jokes you need to understand to truly feel French. Retrieved 31 August, 2018 from French Together: https://frenchtogether.com/french-jokes/

Howe, N. E. (2002). 'The origin of humor'. Medical Hypotheses 59 (3), pp. 252-254.

Levisen, C. (2018). 'Dark, but Danish: Ethnopragmatic perspectives on black humor' Intercultural Pragmatics, Special Issue: "Conversational humour: Forms, functions and practices across cultures", Béal, C. \& Mullan, K. (eds.), 15 (4), pp. 515-531. Doi: 10.1515/ip-2018-0018

Levisen, C. (2019). 'The cultural semantics of untranslatables: Linguistic worldview and the Danish language of laughter', in Głaz, A., (ed.), Languages - Cultures - Worldviews: Focus on Translation, London: Palgrave Macmillan, pp. 319-346. Doi: 10.1007/978-3-03028509-8_13

Levisen, C. \& Waters, S. (2015). 'Lige, a Danish 'magic word'? An ethnopragmatic analysis'. International Journal of Language and Culture, Special Issue: "Language and Cultural Values: Adventures in Applied Ethnolinguistics", Peeters, B. (ed.), 2 (2), pp. 244 -268. Doi: 10.1075/ijolc.2.2.05lev

Levisen, C. \& Waters, S. (2017). 'How words do things with people', in Levisen, C. \& Waters, S. (eds.), Cultural Keywords in Discourse, Amsterdam: John Benjamins, pp. 1-23. Doi: 10.1075/pbns.277.01lev

Lundquist, L. (2014). 'Danish humour in cross-cultural professional settings: Linguistics and social aspects'. Humor: International Journal of Humor Research 27 (1), pp. 141-163. Doi: 10.1515/humor-2013-0044

Maurin, D., Pacault, C. \& Galès, B. (2014). 'Les blagues sont des vecteurs de stéréotypes. Exemple de la profession médicale à partir de 220 blagues'. La Presse Médicale 43 (12), pp. e385-e392.

Mayes, I. (2002, December 2). 'Barrack room blaggards'. The Guardian. Retrieved 15 January, 2020 from https://www.theguardian.com/comment/story/0,3604,851752,00.html 
Mullan, K. \& Béal, C. (2018). 'Conversational humor in French and Australian English: What makes an utterance (un)funny?'. Intercultural Pragmatics, Special Issue: “Conversational humour: Forms, functions and practices across cultures”, Béal, C. \& Mullan, K. (eds.), 15 (4), pp. 457-485. Doi: 10.1515/ip-2018-0016

Noonan, W. (2011). 'Reflecting back, or what can the French tell the English about humour?' Sydney Studies in English 37, pp. 92-115. Retrieved 31 August, 2018 from https://openjournals.library.sydney.edu.au/index.php/SSE/article/view/5321

Oxford University Press. (2019a). "blag, v. and blag, n.”. Retrieved 1 July, 2019 from https://www.lexico.com/en

Oxford University Press. (2019b). “blague, n.”. Retrieved 1 July, 2019 from https://www.lexico.com/en

Partridge, E. $8^{\text {th }}$ edition. (1984). A Dictionary of Slang and Unconventional English Colloquialisms and Catch Phrases, Fossilised Jokes and Puns, General Nicknames, Vulgarisms and such Americanisms as Have Been Naturalised. Abingdon: Routledge.

Peeters, B. (2006). Semantics Primes and Universal Grammar: Empirical Evidence from the Romance Languages. Amsterdam: John Benjamins.

Professeur V. (2017). Tout savoir sur l'expression Pas de bras, pas de chocolat. Retrieved 31 August, 2018 from http://l-anecdote.com/expression-pas-de-bras-pas-de-chocolat/

Provine, R. (2000). Laughter: A Scientific Investigation. New York: Penguin.

Redfern, W. D. (1996). 'Blague hard!'. Language \& Communication 16 (4), pp. 395-399.

Redfern, W. D. (2005). 'Upping the ante/i: Exaggeration in Céline and Vallés', in Garfitt, T., McMorran, E. \& Taylor, J., (eds.), The Anatomy of Laughter, London: Legenda, pp. 5057.

Rey-Debove, J. \& Rey, A. (2005). Le Petit Robert de la Langue Française: Dictionnaire alphabétique et analogique de la langue française. Paris: Dictionnaires Le Robert.

The Oxford English Dictionary (2 ${ }^{\text {nd }}$ ed.) (1989) Oxford: Clarendon Press.

TLFi: Trésor de la Langue Française informatisé, Retrieved 2 February 2019 from http://atilf.atilf.fr/ ATILF - CNRS \& Université de Lorraine.

Twinsmatique Jules et Adrien. (2017, July, 4). Qu'est-ce qui est jaune et qui attend? [video file]. Retrieved 31 August, 2018 from https://youtu.be/etoDNEDD5mg.

Very droll; French humour. (2003, December 20). The Economist, 369 (8355), pp. 59-76. Retrieved 31 August, 2018 from https://www.economist.com/christmas-specials/2003/ $12 / 18 /$ very-droll

Voltaire (1827). Euvres complètes de Voltaire. Tome Troisième. Sautelot et co: Paris.

Wierzbicka, A. (2014a). Imprisoned in English: The Hazards of English as the Default Language. New York: Oxford University Press.

Wierzbicka, A. (2014b). "Pain" and "suffering" in cross-linguistic perspective'. International Journal of Language \& Culture 1 (12), pp. 149-173. Doi: 10.1075/ijolc.1.2.02wie 